(c) American Dairy Science Association, 2006.

\title{
Effects of Supplementing Concentrates Differing in Carbohydrate Composition in Veal Calf Diets: I. Animal Performance and Rumen Fermentation Characteristics ${ }^{1}$
}

\author{
B. J. Suárez, ${ }^{\star 2}$ C. G. Van Reenen,† G. Beldman,‡ J. van Delen,† J. Dijkstra, ${ }^{\star}$ and W. J. J. Gerrits* \\ *Animal Nutrition Group, Wageningen UR, P.O. Box 338, 6700 AH Wageningen, The Netherlands \\ †Animal Sciences Group of Wageningen UR, P.O. Box 65, 8200 AB Lelystad, The Netherlands \\ ‡Department of Food Technology and Nutritional Sciences, Wageningen UR, 6703 HD Wageningen, The Netherlands
}

\begin{abstract}
The aim of this experiment was to examine the effects of concentrates in feed, differing in carbohydrate source, on the growth performance and rumen fermentation characteristics of veal calves. For this purpose, 160 Holstein Friesian $\times$ Dutch Friesian crossbred male calves were used in a complete randomized block design with a $5 \times 2$ factorial arrangement. Dietary treatments consisted of 1) milk replacer control, 2) pectin-based concentrate, 3) neutral detergent fiber-based concentrate, 4) starch-based concentrate, and 5) mixed concentrate (equal amounts of concentrates of treatments 2 , 3 , and 4). Concentrate diets were provided as pellets in addition to a commercial milk replacer. Calves were euthanized either at the end of 8 or 12 wk of age. The overall dry matter intake of the concentrate diets varied between 0.37 and $0.52 \mathrm{~kg} / \mathrm{d}$. Among the concentrate diets, the dry matter intake was lower in the starch diet $(0.37 \mathrm{~kg} / \mathrm{d}$ of dry matter) and differed between the $\mathrm{NDF}$ and pectin diets. The average daily gain for all the dietary treatments varied between 0.70 and 0.78 $\mathrm{kg} / \mathrm{d}$. The mixed- and NDF-fed calves had an increased average daily gain $(0.78$ and $0.77 \mathrm{~kg} / \mathrm{d}$, respectively) compared with the starch- and pectin-fed calves $(0.70$ and $0.71 \mathrm{~kg} / \mathrm{d}$, respectively). Rumen fermentation in the calves fed concentrates was characterized by a low $\mathrm{pH}$ (4.9 to 5.2), volatile fatty acid concentrations between 100 and $121 \mathrm{mmol} / \mathrm{L}$, and high concentrations of reducing sugars (33 to $66 \mathrm{~g} / \mathrm{kg}$ of dry matter). The volatile fatty acid concentrations of calves fed concentrates were higher than those of the control calves. All concentrate treatments showed a low acetate-to-propionate ratio in rumen fluid (between 1.3 and 1.9). Among the concentrates, the NDF diet had the highest (55.5\%) and
\end{abstract}

Received December 23, 2005.

Accepted June 20, 2006.

${ }^{1}$ This study was partially supported by the Dutch Product Board Animal Feed and the Dutch Ministry of Agriculture.

${ }^{2}$ Corresponding author: Bernardo.Suarez@wur.nl starch the lowest (45.5\%) molar proportions of acetate. Calves fed the mixed, pectin, and starch diets had significantly higher molar proportions of butyrate (13.1 to $15.8 \%$ ) than the NDF- and control-fed groups (9.9 and $9.6 \%$, respectively). Calves fed the control diet had a higher lactate concentration $(21 \mathrm{mmol} / \mathrm{L})$ than the concentrate-fed calves (between 5 and $11 \mathrm{mmol} / \mathrm{L}$ ). With the exception of the NDF diet, polysaccharide-degrading enzyme activities in the rumen contents generally showed an adaptation of the microorganisms to the carbohydrate source in the diet. The mixed diet exhibited the least variation in rumen polysaccharide-degrading enzyme activities among the enzymes systems tested. Results indicated that the carbohydrate source can influence intake, growth rate, and rumen fermentation in young veal calves.

Key words: veal calf, concentrate feed composition, rumen fermentation, enzyme activity

\section{INTRODUCTION}

Traditionally, veal calves were fed until slaughter weight with milk replacer without the provision of concentrates. However, the absence of solid feed limits the physiological development of the forestomachs. Furthermore, provision of solid feed has reduced abnormal oral behaviors (Van Putten, 1982; Veissier et al., 1998). In 1997, new European Union legislation stipulated that a minimum amount of solid feed (fiber) must be provided for the welfare of the calves; however, no specifications were made about the type and source of feed.

Rumen development is triggered by the production of VFA resulting from fermentation of $\mathrm{OM}$ in the rumen (Flatt et al., 1958). Butyrate, and to a lesser extent propionate, stimulate the development of the rumen mucosa, mostly because of their use as energy sources by the rumen epithelium (Sander et al., 1959; Tamate et al., 1962). Since the early 1970 s, extensive research has evaluated different protein and carbohydrate sources in calf starters. To date, only a few experiments have evaluated the effect of concentrate supplementa- 
tion on performance and rumen development in veal calves. Concentrate feeds, as opposed to roughages, are provided to young calves to obtain high DMI and subsequent rapid VFA production, promoting fast papillae growth and rumen development. However, when compared with rearing calves, the DMI of concentrates in veal calves is hampered by high intakes of milk replacer. In addition, milk replacer intake may influence the fermentation process in the rumen. Consequently, the present study was conducted to evaluate the effects of intake of concentrates differing in their carbohydrate composition in addition to a milk replacer on the performance and rumen fermentation characteristics of veal calves. The effects of these diets on morphological rumen development are presented in a companion paper (Suárez et al., 2006).

\section{MATERIALS AND METHODS}

The present experiment was conducted at the experimental farm of Wageningen University \& Research Centre (ID Lelystad, The Netherlands) in compliance with the Dutch law on experimental animals.

\section{Calves and Diet Transport and Slaughter Procedure}

One hundred and sixty male Holstein Friesian $\times$ Dutch Friesian calves, averaging $44.9 \mathrm{~kg}$ of BW (SE = $2.8 \mathrm{~kg}$ ) were purchased in 2 batches of 80 animals. On arrival, calves were weighed and, based on their BW, assigned to 1 of 8 blocks. Within blocks and batches, calves were randomly assigned to 1 of 5 dietary treatments and 1 of 2 slaughter ages. The dietary treatments included a milk-fed control and 4 treatments in which a concentrate, varying in carbohydrate composition, was fed in addition to the milk replacer: 1) milk replacer (control); 2) pectin-based concentrate; 3) NDF-based concentrate; 4) starch-based concentrate; or 5) mixed concentrate (equal amounts of the concentrates in treatments 2,3 , and 4). The detailed ingredient and nutrient compositions of the concentrates are presented in Table 1. Animals were individually housed in open metal boxes $\left(0.9 \mathrm{~m}^{2}\right)$ with a wooden slatted floor, without bedding material. Boxes were located in 2 stables, where the environmental temperature was maintained at least at $15^{\circ} \mathrm{C}$. In treatments 2 to 5 , concentrates were provided as pellets, up to a maximum of $750 \mathrm{~g} / \mathrm{d}$ of DM. Milk replacer and concentrates were supplied in separate buckets and meals were supplied in equal amounts twice daily (0730 and $1830 \mathrm{~h}$ ). For the pelleting process, special care was taken to minimize particle size reduction of the ingredients. Therefore, corn was only broken and barley was rolled prior to inclusion; soybean hulls (beans dehulled after toasting) and corn grits were not further ground before pelleting. Sugar beet pulp (without molasses) was ground through a 2.75-mm screen on a hammer mill prior to pelleting. The average pellet size was $15 \mathrm{~mm}$ long and $6 \mathrm{~mm}$ in diameter.

The amount of milk replacer provided to, and hence consumed by, the calves (grams per day per calf) is shown in Table 2, and its nutrient and ingredient composition is presented in Table 3 . For the control treatment, milk replacer was reconstituted in a ratio of $\approx 130$ $\mathrm{g} / \mathrm{L}$ of water and provided in 2 equal meals at $39^{\circ} \mathrm{C}$. For treatments with additional solid feed (treatments 2 to 5 ), the amount of milk replacer was reduced to stimulate the intake of solid feed (see Table 2) and reconstituted in the same volume of water as the control group. Calves were weighed every $4 \mathrm{wk}$, and once a week samples of milk replacer and concentrates were collected and pooled by month for further analysis.

Animals were killed at the end of either an 8- or 12wk feeding period, by a dose application of T61 (embutramide/mebezoniumiodide/tetracain hydrochloride, Intervet International, Unterschleissheim, Germany). The slaughter activity took place in the pathology laboratory of the Research Center, located 5 min from the experimental farm. Before slaughter, calves received only milk replacer and were euthanized within a range of 1 to $3 \mathrm{~h}$ after feeding. The sequence of slaughter was properly balanced across treatments. The reticulorumen (hereafter rumen) and the abomasum were tied at the end of the esophagus and pylorus, respectively, and removed. The rumen was dissected along the dorsal line, emptied, and weighed. The rumen contents were weighed, and representative samples of the contents were taken. A full description of the slaughter procedure is provided in the companion paper (Suárez et al., 2006). Samples of rumen contents were immediately cooled on ice and stored at $-20^{\circ} \mathrm{C}$ until analysis. After centrifugation of the rumen contents $(1,000 \times g$ for 10 $\min ), \mathrm{pH}$ was measured in the supernatant and a 5$\mathrm{mL}$ aliquot was acidified with $1 \mathrm{~mL}$ of $5 \%$ ortho-phosphoric acid and stored at $-20^{\circ} \mathrm{C}$ until further analysis.

\section{Analytical Procedures}

Dry matter was determined by drying at $103^{\circ} \mathrm{C}$ to a constant weight (ISO 6496; ISO, 1983) and ash by combustion at $550^{\circ} \mathrm{C}$ (ISO 5984; ISO, 1978). Crude fat was determined by extraction with petroleum ether (boiling range 40 to $60^{\circ} \mathrm{C}$ ). After extraction, samples were dried in a vacuum oven at $80^{\circ} \mathrm{C}$ to a constant weight, according to ISO 6492 (ISO, 1985). Nitrogen was determined with the Kjeldahl method with $\mathrm{CuSO}_{4}$ as the catalyst (ISO 5983; ISO, 1998). Total starch was analyzed by an enzymatic method according to Brunt 
Table 1. Ingredient and analyzed nutrient composition of the concentrates ${ }^{1}$

\begin{tabular}{|c|c|c|c|c|c|}
\hline Item & $\mathrm{IFN}^{2}$ & Pectin & $\mathrm{NDF}$ & Starch & Mixed \\
\hline \multicolumn{6}{|l|}{ Ingredient composition } \\
\hline Beet pulp, ground, \% & $4-00-672$ & 91.3 & - & - & 30.3 \\
\hline Soybean hulls, \% & $1-04-560$ & - & 46.4 & - & 15.5 \\
\hline Corn grits, $\%$ & $4-03-011$ & - & 46.4 & - & 15.5 \\
\hline Corn, \% & $4-20-689$ & - & - & 46.4 & 15.5 \\
\hline Barley, crushed, \% & $4-00-549$ & - & - & 46.4 & 15.5 \\
\hline Soybean oil, \% & NA & 1.5 & - & - & 0.5 \\
\hline Solpro $500,{ }^{3} \%$ & NA & 4.0 & 4.0 & 4.0 & 4.0 \\
\hline Urea, \% & NA & 1.2 & 1.2 & 1.2 & 1.2 \\
\hline Vinasse, ${ }^{4} \%$ & NA & 2.0 & 2.0 & 2.0 & 2.0 \\
\hline \multicolumn{6}{|l|}{ Analyzed nutrient composition } \\
\hline $\mathrm{DM}, \mathrm{g} / \mathrm{kg}$ of product & & 890.6 & 901.7 & 887.5 & 892.1 \\
\hline $\mathrm{CP}, \mathrm{g} / \mathrm{kg}$ of $\mathrm{DM}$ & & 178.1 & 194.4 & 180.6 & 185.0 \\
\hline Crude fat, g/kg of DM & & 30.1 & 30.7 & 31.6 & 30.5 \\
\hline Crude ash, $\mathrm{g} / \mathrm{kg}$ of DM & & 64.0 & 32.8 & 25.8 & 41.0 \\
\hline Starch, g/kg of DM & & 22.4 & 107.9 & 592.8 & 243.9 \\
\hline Sugars, glucose g/kg of DM & & 64.8 & 25.8 & 27.7 & 35.2 \\
\hline $\mathrm{NDF}, \mathrm{g} / \mathrm{kg}$ of DM & & 340 & 493 & 94 & 308 \\
\hline $\mathrm{ADF}, \mathrm{g} / \mathrm{kg}$ of $\mathrm{DM}$ & & 206 & 265 & 32 & 163 \\
\hline Acid detergent lignin, $\mathrm{g} / \mathrm{kg}$ of $\mathrm{DM}$ & & 11 & 9 & 6 & 9 \\
\hline $\mathrm{Ca}, \mathrm{g} / \mathrm{kg}$ of $\mathrm{DM}$ & & 8.1 & 4.1 & 1.2 & 4.1 \\
\hline $\mathrm{P}, \mathrm{g} / \mathrm{kg}$ of $\mathrm{DM}$ & & 1.3 & 2.0 & 3.7 & 2.3 \\
\hline $\mathrm{Na}, \mathrm{g} / \mathrm{kg}$ of $\mathrm{DM}$ & & 0.8 & 0.9 & 0.7 & 0.7 \\
\hline $\mathrm{K}, \mathrm{g} / \mathrm{kg}$ of $\mathrm{DM}$ & & 6.0 & 10.5 & 6.9 & 7.6 \\
\hline $\mathrm{Mg}, \mathrm{g} / \mathrm{kg}$ of $\mathrm{DM}$ & & 2.3 & 2.0 & 1.5 & 1.8 \\
\hline $\mathrm{Fe}, \mathrm{mg} / \mathrm{kg}$ of $\mathrm{DM}$ & & 757 & 325 & 106 & 386 \\
\hline
\end{tabular}

${ }^{1}$ Diets were as follows: pectin = pectin-based concentrate; NDF = NDF-based concentrate $;$ starch = starchbased concentrate; mixed = mixed concentrate (equal amounts of the pectin-, NDF-, and starch-based concentrates).

${ }^{2}$ IFN = International Feed Number (obtained from NRC, 1989). NA = Not available.

${ }^{3}$ Solpro, Tate \& Lyle, Amylum Group, Burchstraat, Belgium.

${ }^{4}$ Vinasse $=$ A residue of alcohol distillation from sugar cane.

(1993). Reducing sugars (RS) were extracted from the samples using $40 \%$ ethanol and subsequent hydrolysis in a weak acid environment. Protein was precipitated using a Carrez I and II solution. After the hydrolysis, copper(II) was reduced by oxidation of the monosaccharides to copper(I). Copper(I) forms a yellow complex with neocuproïne (2,9-dimethyl-1,10-fenantroline hydrochloride). This complex can be measured in a spectrophotometer at $460 \mathrm{~nm}$.

The NDF analysis was based on the method of Van Soest et al. (1991) but included, after the neutral detergent treatment incubation, an enzyme cocktail containing termamyl (Novo Nordisk, Copenhagen, Denmark), amylase (Sigma 6814; Sigma-Aldrich, St. Louis,
MO), and protease (Novo Nordisk) in phosphate buffer $(\mathrm{pH}$ 7.0) to remove starch and proteins from the residue. The ADF analysis involved 2 steps. First, the sample was treated according to the NDF method described. In the second step, the neutral detergent residue was treated with the acid detergents as described by Van Soest and McQueen (1973). The acid detergent lignin analysis was based on the treatment of the sample with acid detergent, followed by incubation with $72 \%$ sulfuric acid.

Volatile fatty acid concentrations and lactic acid were analyzed using HPLC with a Merck polyspher OA 51272 column as the stationary phase (Merck \& Co., Inc., Whitehouse Station, NJ) and $0.0025 M$ sulfuric

Table 2. Milk replacer supplied and consumed throughout the experiment (g/calf per d) ${ }^{1}$

\begin{tabular}{|c|c|c|c|c|c|c|c|c|c|c|c|c|}
\hline Scheme & \multicolumn{12}{|c|}{ Week of trial } \\
\hline Control & 380 & 490 & 680 & 910 & 1,140 & 1,370 & 1,500 & 1,520 & 1,590 & 1,720 & 1,870 & 1,950 \\
\hline
\end{tabular}

${ }^{1}$ Because calves always consumed the whole portion of the supplied milk replacer. 
Table 3. Ingredient and analyzed nutrient composition of milk replacer (in product)

\begin{tabular}{lc}
\hline Item & Amount \\
\hline Ingredient composition & \\
Whey protein concentration, \% & 50 \\
Whey powder, \% & 27 \\
Oil and fat, $\%$ & 17 \\
Delactosed whey powder, \% & 5 \\
Vitamin-mineral mix, ${ }^{1} \%$ & 1 \\
Nutrient composition & \\
Nitrogen, g/kg & 35.4 \\
Crude fat, g/kg & 180 \\
Ash, g/kg & 73.3 \\
Moisture, g/kg & 28.7 \\
Ca, g/kg & 6.9 \\
P, g/kg & 5.3 \\
Na, g/kg & 4.8 \\
$\mathrm{~K}, \mathrm{~g} / \mathrm{kg}$ & 17.1 \\
$\mathrm{Mg}, \mathrm{g} / \mathrm{kg}$ & 1.4 \\
\hline
\end{tabular}

${ }^{1}$ Coconut oil and partly hydrogenated soybean oil.

${ }^{2}$ Provided (per kilogram of milk replacer): vitamin A, 25,000 IU; vitamin $\mathrm{D}_{3}, 2,000 \mathrm{IU}$; vitamin $\mathrm{E}, 80 \mathrm{mg}$; vitamin $\mathrm{C}, 80 \mathrm{mg}$; Ca, 7.8 g; P, 6.5 mg; Mg, 1.4 g; Zn, 40 mg; Cu, 10 mg; Mn, 30 mg; Se, 0.15 $\mathrm{mg}$; Fe, $33 \mathrm{mg}$.

acid as the mobile phase (elution fluid). Detection was performed by using a refractive index detector. Calibration and quantification was done by using an external standard solution. Ammonia concentrations were estimated according to the method of Berthelot, modified by Schneider (1976).

Isolation of rumen enzymes and subsequent measurement of their activities were performed as follows. Whole rumen contents of 8 of the 16 calves per treatment, slaughtered at 12 wk of age, were used. The intraand extracellular microbial enzymes and those enzymes attached to rumen particles were extracted from whole rumen contents. A combination of methods was applied to maximize the extraction of enzymes from the homogenized whole rumen contents, obtained at slaughter (i.e., freezing and thawing, sonication, and osmotic shock). After thawing, samples were kept on ice and sonified (Branson Sonifier 250; Branson Ultrasonics Corporation, Danbury, CT), using a flat tip (1/2-in. diameter), for $2 \mathrm{~min}$ (at $40 \%$ of the duty cycle) in a 50 $\mathrm{m} M$ sodium acetate $(\mathrm{NaAc})$ buffer $(\mathrm{pH} 5)$ including 2 $M \mathrm{NaCl}$ and $0.01 \% \mathrm{NaN}_{3}$. Subsequently, feed particles and lysed bacteria were removed (centrifugation at $20,000 \times g, 22.5 \mathrm{~min}, 4^{\circ} \mathrm{C}$ ) and the enzyme cocktail obtained was dialyzed (dialysis tubing: size 5 i.d.; 24/ 32-in.; $19.0 \mathrm{~mm}$; $30 \mathrm{M}$; approximately 12,000 to 14,000 Da; Medicell International, Liverpool, UK) against a 50 $\mathrm{m} M \mathrm{NaAc}$ buffer ( $\mathrm{pH} 5.0,18 \mathrm{~h}, 4^{\circ} \mathrm{C}$ ) to remove dissolved sugars and $\mathrm{NaCl}$. Changes in volume during dialysis were recorded. Enzyme activity was determined by the release of RS after $60 \mathrm{~min}$ of incubation of $0.5 \mathrm{~mL}$ of the enzyme cocktail with $0.5 \mathrm{~mL}$ of $120 \mathrm{~m} M \mathrm{NaAc}$ buffer
(pH 5.0) and $0.5 \mathrm{~mL}$ of each of 4 substrate suspensions in an Eppendorf mixer at $39^{\circ} \mathrm{C}$. The reaction was stopped at $100^{\circ} \mathrm{C}$ after $5 \mathrm{~min}$. The substrate suspensions (sugar beet pulp, sugar beet pectin, soybean hulls, and native cornstarch, $2 \% \mathrm{wt} / \mathrm{vol}$ ) provided excess substrate for the incubations and were prepared in demineralized water containing $0.01 \% \mathrm{NaN}_{3}$, and kept overnight at $39^{\circ} \mathrm{C}$ in a water bath before use. Incubates, substrate blanks, and enzyme extract blanks were analyzed for reducing sugar end-groups according to Somogyi (1952). Enzyme activity was expressed as millimoles of $\mathrm{RS}$ released per minute per gram of DM in the rumen.

\section{Statistical Analysis}

Data for DMI, average daily gain (ADG), and blood and rumen parameters were analyzed as a complete randomized block design, in a $5 \times 2$ factorial arrangement, with diets and length of the experimental period (i.e., 8 or $12 \mathrm{wk}$ of age at slaughter) as main factors. Continuous data were subjected to ANOVA, according to Model 1:

$$
\begin{aligned}
\mathrm{y}= & \mu+\text { batch }_{\mathrm{i}}+\operatorname{diet}_{\mathrm{j}}+\text { period }_{\mathrm{k}} \\
& +\left(\operatorname{diets} \times \text { period }_{\mathrm{jk}}+\varepsilon_{\mathrm{ijkl}}\right.
\end{aligned}
$$

where $\mathrm{y}$ is the dependent variable; $\mu$ is the average experimental value; batch $_{i}$ is the effect of batch $i$; $i$ is 1 of 2 ( 2 batches of 80 calves); diet ${ }_{j}$ is the effect of dietary treatment $j ; j$ is the control, pectin, NDF, starch, or mixed diet; period $_{\mathrm{k}}$ is the effect of period (age at slaughter) $\mathrm{k}$; $\mathrm{k}$ is 8 or $12 \mathrm{wk}$; (diet $\times$ period) $\mathrm{jk}_{\mathrm{jk}}$ is the effect of the interaction between diet and period; $\varepsilon_{\mathrm{ijkl}}$ is an error term; and $l$ is $1, \ldots, 160$.

The main effects and the interaction between diet and time of the experiment (age at slaughter) were evaluated using the $F$-test, followed by posthoc pairwise comparisons (Fisher LSD method) when the $F$-value showed significance $(P<0.05)$. Rumen parameters were also subjected to an analysis of covariance. The average DMI during the last week prior to slaughter, expressed for each calf as the deviation from the overall mean, was included as a covariable in Model 1. For calves in the control treatment, the covariable was equal to 0 . The statistical analyses were carried out using Genstat (Genstat Committee, 2000). The rumen enzyme activities were analyzed as a split-plot design using the GLM procedure of SAS (SAS Institute, 2002) according to Model 2:

$$
\begin{gathered}
\mathrm{y}=\mu+\operatorname{diet}_{\mathrm{i}}+\left(\operatorname{diet} \times \text { calf }_{\mathrm{ij}}+\text { substrate }_{\mathrm{k}}\right. \\
+(\operatorname{diet} \times \text { substrate })_{\mathrm{ik}}+\varepsilon_{\mathrm{ijkl}}
\end{gathered}
$$


Table 4. Effects of period (age at slaughter) and diets (supplemented concentrates differing in carbohydrate source) on concentrate DMI and average daily gain $(\mathrm{ADG})^{1}$

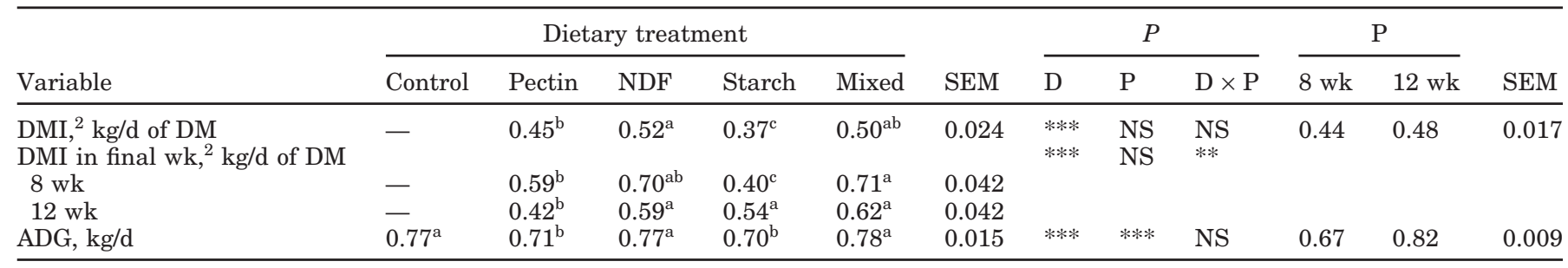

${ }^{\mathrm{a}-\mathrm{c}}$ Means in the same row with different superscripts differ $(P<0.05)$. NS $=$ not significant.

${ }^{1}$ Diets were as follows: control = milk replacer; pectin = pectin-based concentrate; NDF = NDF-based concentrate; starch = starch-based concentrate; mixed = mixed concentrate (equal amounts of the pectin-, NDF-, and starch-based concentrates). D = diet; $\mathrm{P}=$ period (age at slaughter); $\mathrm{D} \times \mathrm{P}=$ interaction.

${ }^{2}$ Excluding DMI from milk.

$* * P \leq 0.01 ; * * * P \leq 0.001$.

where $\mathrm{y}$ is the dependent variable; $\mu$ is the average experimental value; diet $_{i}$ is the effect of dietary treatment $i, i$ is the control, pectin, NDF, starch, or mixed diet; calf $\mathrm{j}_{\mathrm{j}}$ is the effect of calf $\mathrm{j}, \mathrm{j}$ is $1,2,3, \ldots, 40$; substrate $_{\mathrm{k}}$ is the effect of substrate $\mathrm{k}$; $\mathrm{k}$ is soybean hulls, native cornstarch, sugar beet pectin, and sugar beet pulp; and $\varepsilon_{\mathrm{ijkl}}$ is an error term.

Diet was considered as the main plot factor and substrate as the subplot. The term diet $\times$ calf was used as an error term to test the effect of the diet. Other effects were tested against the residual error term. The Tukey test was used to test for all pairwise comparisons among means when the $F$-value was significant $(P<0.05)$.

\section{RESULTS}

\section{Feed Intake and BW Gain}

All calves remained healthy throughout the experiment. Table 4 shows the effects of experimental treatments on concentrate DMI and on ADG. The averaged DMI of the concentrate diets varied between 0.37 and $0.52 \mathrm{~kg} / \mathrm{d}$ of DM. Calves receiving the starch diet showed the lowest DMI $(0.37 \mathrm{~kg} / \mathrm{d}$ of DM) throughout the trial. The DMI of the NDF diet was higher than that of the pectin $\operatorname{diet}(P<0.05)$. A diet effect $(P<0.001)$ and diet $\times$ period interaction $(P<0.01)$ were observed in the last week of the experiment. First, for calves in the last week of the 8-wk period, the DMI of the starch diet was the lowest $(0.40 \mathrm{~kg} / \mathrm{d}$ of $\mathrm{DM})$ among the concentrate treatments. Calves fed the pectin diet had a lower DMI $(0.59 \mathrm{~kg} / \mathrm{d}$ of $\mathrm{DM})$ than those fed the mixed diet $(0.71$ $\mathrm{kg} / \mathrm{d}$ of DM). Second, in the last week of the 12 -wk period, the diet $\times$ period interaction was due to a common decrease on DMI for the concentrate diets but an increase for the starch diet.

The ADG for all the dietary treatments varied between 0.70 and $0.78 \mathrm{~kg} / \mathrm{d}$, being affected by diet and period $(P<0.001)$. The daily BW gains of the calves fed the NDF $(0.77 \mathrm{~kg} / \mathrm{d})$ and mixed $(0.78 \mathrm{~kg} / \mathrm{d})$ diets were higher $(P<0.05)$ than for those fed either the pectin $(0.71 \mathrm{~kg} / \mathrm{d})$ or the starch diet $(0.70 \mathrm{~kg} / \mathrm{d})$. Because of the different amounts of milk replacer supplied to the calves fed concentrate diets (Table 2), a direct comparison of the feed conversion of those treatments with the milk fed-only calves cannot be done. An analysis of the growth performance is presented in the Discussion section.

\section{Rumen Fermentation Characteristics}

Table 5 shows the results of the analysis performed on the samples of rumen contents. The $\mathrm{pH}$ of the rumen liquid varied between 4.9 and 5.6 and was affected by diet and period $(P<0.001)$. An interaction between diet and period also was observed $(P<0.05)$. This interaction was caused by the rise in $\mathrm{pH}$ of the control treatment from 5.2 to 5.6 from wk 8 to 12 , respectively, while remaining constant in the calves fed concentrates. An exception was the starch diet, which was 4.9 at the end of the 8-wk period and increased to 5.2 at the end of wh 12.

The total VFA concentrations were affected by dietary treatments $(P<0.001)$, but not by period or by the interactions between treatment and period. All concentrate treatments showed higher total VFA concentrations in rumen fluid (100 to $121 \mathrm{mmol} / \mathrm{L}$ ) compared with the control treatment $(36 \mathrm{mmol} / \mathrm{L})$. In addition, the total VFA concentration of the starch diet was lower $(100 \mathrm{mmol} / \mathrm{L} ; P<0.05)$ when compared with the other concentrate-based treatments. The calves fed the NDF diet had the highest molar proportion of acetate (55.5\%) among the concentrates and starch had the lowest (45.5\%). Furthermore, starch-fed calves showed the highest molar proportions of propionate (33.9\%). Finally, the molar proportion of butyrate was significantly 
Table 5. Effects of period (age at slaughter) and diets (supplemented concentrates differing in carbohydrate source) on rumen fermentation characteristics $^{1}$

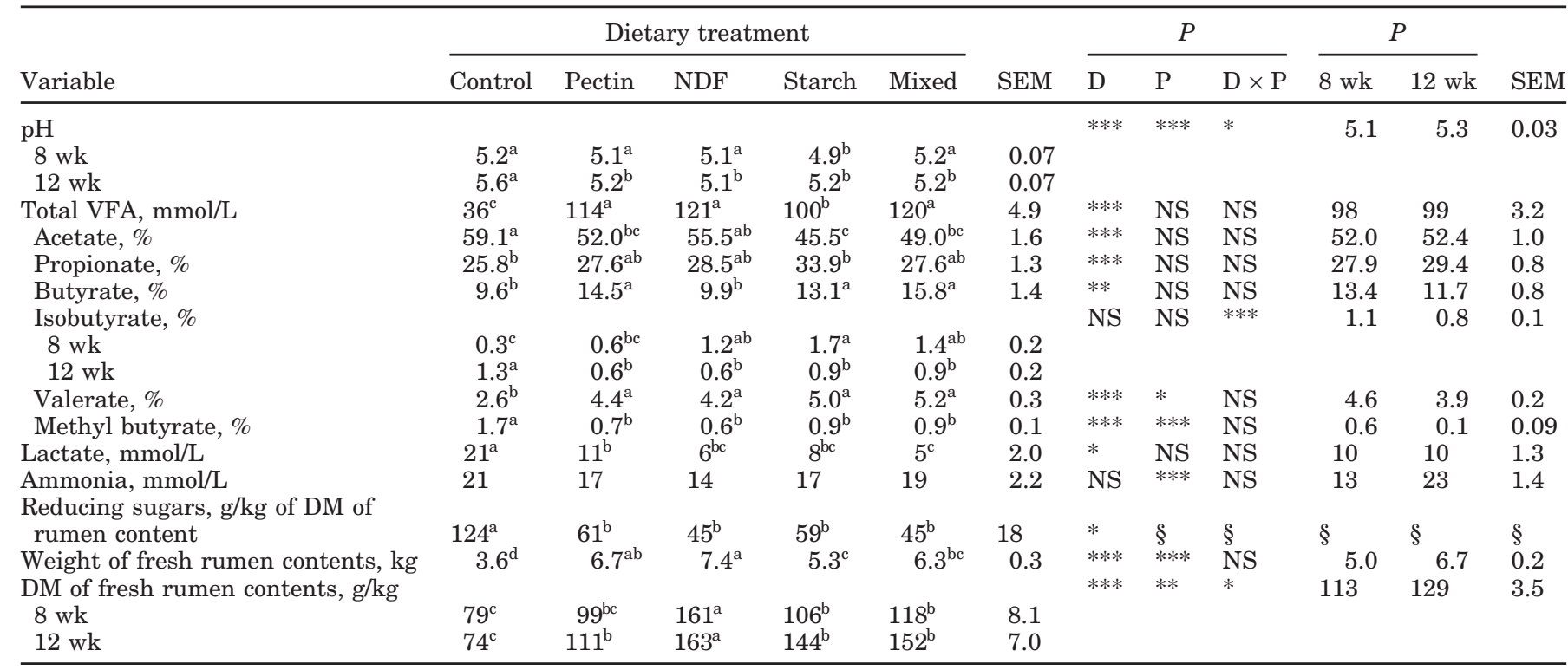

${ }^{\mathrm{a}-\mathrm{c}}$ Means in the same row with different superscripts differ $(P<0.05)$. NS $=$ not significant.

${ }^{1}$ Diets were as follows: control $=$ milk replacer; pectin $=$ pectin-based concentrate; NDF $=$ NDF-based concentrate; starch = starch-based concentrate; mixed = mixed concentrate (equal amounts of the pectin-, NDF-, and starch-based concentrates). D = diet; $\mathrm{P}=$ period (age at slaughter); $\mathrm{D} \times \mathrm{P}=$ interaction. §Only samples of 12 wk were analyzed.

$* P \leq 0.05 ; * * P \leq 0.01 ; * * * P \leq 0.001$.

higher for calves fed the mixed, pectin, and starch diets (13.1 to 15.8\%) compared with the NDF- and control-fed groups (9.9 and $9.6 \%, P<0.01$ ). The molar proportion of isobutyrate in the rumen liquid was affected by an interaction between diet and period $(P<0.05)$. This interaction was caused by a rise in the molar proportion of isobutyrate of the control treatment from 0.3 to $1.3 \%$, whereas a decrease in the molar proportion of isobutyrate was observed in the calves fed concentrates from wk 8 to 12 , respectively, with the exception of the pectin diet. With respect to the molar proportions of valerate and methyl butyrate in the rumen liquid, no differences were found between the concentrate diets, but they were higher than the control $(P<0.05)$. Moreover, for both acids a period effect was observed, with decreased molar proportions for valerate $(P<0.05)$ and increased molar proportions for methyl butyrate $(P<$ $0.001)$ at $12 \mathrm{wk}$, respectively. Lactate concentrations in the rumen fluid were significantly different between treatments $(P<0.05)$. Animals fed the control diet had elevated lactate concentrations $(21 \mathrm{mmol} / \mathrm{L})$ compared with concentrate-fed animals (ranging between 5 and $11 \mathrm{mmol} / \mathrm{L}$ ). Also, lactate concentrations in the rumen fluid of calves fed the pectin diet were twice as high as in those fed the mixed concentrate $(P<0.05)$. The amount of reducing sugars in the rumen content varied between 45 and $124 \mathrm{~g} / \mathrm{kg}$ of DM. Calves fed the control diet showed a higher amount of reducing sugars than calves fed the concentrate diets $(P<0.05)$.

The concentration of ammonia in the rumen liquid varied between 14 and $21 \mathrm{mmol} / \mathrm{L}$, and no significant differences between the treatments were observed $(P>$ $0.05)$. The concentration of ammonia in the rumen fluid was significantly $(P<0.001)$ higher at the end of the 12 -wk period $(23 \mathrm{mmol} / \mathrm{L})$ than at the end of the 8 -wk period $(13 \mathrm{mmol} / \mathrm{L})$.

The analysis of covariance revealed that the variation in DMI did not significantly explain the variation in total VFA or its molar proportions. For $\mathrm{pH}$ of the rumen fluid and for concentrations of lactate and $\mathrm{NH}_{3}$, the inclusion of DMI as a covariable appeared significant (estimates of regression coefficients \pm SE for DMI: 0.4 $\pm 0.1,-13.3 \pm 5.9$, and $-15.2 \pm 6.3$, respectively; $P<$ $0.05)$. Following the analysis of covariance, differences in the rumen lactate concentrations between the control, the pectin, and the mixed diets remained as presented. However, the difference between the pectin and mixed diets was decreased (predicted means 10 vs. 6 $\mathrm{mmol} / \mathrm{L}, P=0.20$ ) after the analysis of covariance. The effects on ammonia concentrations did not change. Likewise, for rumen $\mathrm{pH}$, inclusion of the covariable increased the $P$-value for the interaction between diet and period (from $P=0.03$ to $P=0.06$ ). 
Table 6. Effects of dietary treatment and substrate on enzymes activities $(\mathrm{mmol} / \mathrm{min}$ per $\mathrm{g}$ of $\mathrm{DM})$ of whole rumen content

\begin{tabular}{|c|c|c|c|c|}
\hline \multirow[b]{2}{*}{ Item } & \multicolumn{4}{|c|}{ Substrate } \\
\hline & $\begin{array}{l}\text { Native } \\
\text { cornstarch }\end{array}$ & $\begin{array}{l}\text { Sugar } \\
\text { beet } \\
\text { pulp }\end{array}$ & $\begin{array}{l}\text { Soybean } \\
\text { hulls }\end{array}$ & $\begin{array}{l}\text { Sugar } \\
\text { beet } \\
\text { pectin }\end{array}$ \\
\hline \multicolumn{5}{|l|}{$\operatorname{Diet}^{1}$} \\
\hline Control & $0.6^{\mathrm{aw}}$ & $0.7^{\mathrm{aw}}$ & $0.4^{\mathrm{ay}}$ & $0.4^{\mathrm{aw}}$ \\
\hline Pectin & $4.4^{\text {byx }}$ & $6.2^{\mathrm{abz}}$ & $5.0^{\mathrm{bz}}$ & $8.4^{\mathrm{az}}$ \\
\hline NDF & $2.5^{\mathrm{bxw}}$ & $3.6^{\text {abyx }}$ & $4.0^{\mathrm{abz}}$ & $6.0^{\text {ay }}$ \\
\hline Starch & $9.9^{\mathrm{az}}$ & $2.8^{\mathrm{bxw}}$ & $3.5^{\mathrm{bz}}$ & $2.5^{\text {bxw }}$ \\
\hline Mixed & $6.8^{\text {ay }}$ & $5.5^{\mathrm{abzy}}$ & $4.2^{\mathrm{bz}}$ & $5.3^{\text {byx }}$ \\
\hline SEM & 0.47 & 0.47 & 0.47 & 0.47 \\
\hline \multicolumn{5}{|l|}{ Effect } \\
\hline Diet & & & & \\
\hline Substrate & & & & \\
\hline Diet $\times$ substrate & & & & \\
\hline
\end{tabular}

${ }^{\mathrm{a}, \mathrm{b}}$ Means in the same row with different superscript $\operatorname{differ}(P<0$. 05).

${ }^{\mathrm{w}-\mathrm{z}}$ Means in the same column with different superscript differ $(P$ $<0.05)$.

${ }^{1}$ Diets were as follows: control $=$ milk replacer; pectin $=$ pectinbased concentrate; NDF $=$ NDF-based concentrate; starch $=$ starch based concentrate; mixed $=$ mixed concentrate (equal amounts of the pectin-, NDF-, and starch-based concentrates). $\mathrm{D}=\operatorname{diet} ; \mathrm{P}=$ period (age at slaughter); $\mathrm{D} \times \mathrm{P}=$ interaction.

$* * * P \leq 0.001$

\section{Enzyme Activity in Whole Rumen Contents}

Table 6 shows the effects of experimental treatments on the polysaccharide-degrading enzyme (PDE) activity extracted from the rumen contents. Diet and substrate effects and a diet $\times$ substrate interaction $(P<$ 0.001 ) were observed. When averaged over substrates, PDE activities in the rumen content of calves fed concentrate diets varied between 3.9 and $6.0 \mathrm{mmol} / \mathrm{min}$ per $g$ of DM. Calves fed the pectin diet showed higher PDE activity than those fed either the starch or the $\mathrm{NDF}$ diet (6.0 vs. 4.6 and $3.9 \mathrm{mmol} / \mathrm{min}$ per $\mathrm{g}$ of $\mathrm{DM}$ ), respectively. In addition, the PDE activity of controlfed calves was small $(<1 \mathrm{mmol} / \mathrm{min}$ per $\mathrm{g}$ of DM). When averaged over treatments, the PDE activity ranged from 3.4 to $4.8 \mathrm{mmol} / \mathrm{min}$ per $\mathrm{g}$ of $\mathrm{DM}$, decreasing in the order of native cornstarch, sugar beet pectin, sugar beet pulp, and soybean hulls as substrates $(4.8,4.5$, 3.7 , and $3.4 \mathrm{mmol} / \mathrm{min}$ per $\mathrm{g}$ of DM, $P<0.05)$. Generally, the results in Table 6 illustrate an increased enzyme activity for substrates that were present in the diet [e.g., increased pectin- and sugar beet pulp-degrading (pectinase) activities on the pectin diet and increased starch-degrading (amylase) activity on the starch diet]. However, the NDF diet was an exception to this rule, because it showed higher pectin-degrading activity (pectinase) when compared with degradation of soybean hulls (SBHase; $P<0.05)$. In addition, the highest SBHase activity was observed in calves fed the pectin, not the NDF, diet. The mixed diet induced fairly high activities of all enzymes tested and exhibited the least variation among treatments.

\section{DISCUSSION}

In rearing calves, intake of milk replacer is an important factor influencing DMI (Huber et al., 1984). In the present study, DMI of the concentrate diets varied between 0.37 and $0.52 \mathrm{~kg} / \mathrm{d}$ (Table 4), and calves did not consume the whole concentrate portion fed (maximized at $0.75 \mathrm{~kg} / \mathrm{d}$ of DM). The absence of increased DMI from concentrate with age was likely due to the increased supply of milk replacer at the end of the trial (Table 2). The increase of the starch diet with age was an exception (causing an interaction between treatment and period; Table 2). The low intake of the starch diet in the first period may have been related to the low ruminal $\mathrm{pH}$ observed, because acidosis generally depresses the DMI (Kellaway et al., 1977; Nocek, 1997; Owens et al., 1998).

Calves fed additional concentrates showed an ADG (700 to $780 \mathrm{~g} / \mathrm{d}$ ) close to the ADG of veal calves (Table 4). The higher intake of milk replacer in the control treatment, however, hampers a direct comparison of data performance (and efficiency) across treatments. To facilitate this comparison, growth rates on both levels of milk replacer intake were simulated using the veal calf growth model developed by Gerrits et al. (1997). Extra growth attributable to intake of concentrates could be calculated based on the simulated BW gain on the low intake of milk replacer (Table 7). The simulated daily gain values on the high-milk scheme were in line with the observed values (691 vs. 681 and 841 vs. $864 \mathrm{~g} / \mathrm{d}$ at 8 and 12 wk, respectively). Extra daily gain per kilogram of concentrate ranged from 0.82 to $1.04 \mathrm{~kg}$ and from 0.56 to $0.62 \mathrm{~kg}$ at 8 and $12 \mathrm{wk}$ of the trial period, respectively. At $8 \mathrm{wk}$, calves fed the starch diet showed the highest extra growth, whereas at 12 wk calves fed the starch and mixed diets showed the highest extra growth. Compared with the 8-wk period, at the 12 -wk period the extra growth achieved by all the concentrate treatments may be related to the decline in growth rate and growth efficiency accompanying an increase in BW present in farm animals.

The rumen $\mathrm{pH}$ observed in our experiment was quite low when compared with some studies with rearing calves. However, measurements of ruminal $\mathrm{pH}$ in some early studies with young calves may have been inaccurate because of the method of sampling (e.g., stomach tube) or housing conditions (e.g., straw bedding; Murdock and Wallenius, 1980; Wheeler et al., 1980). Our results were more in line with later studies conducted by Anderson et al. (1987a,b), Beharka et al. (1998), 
Table 7. Intake and simulated and observed daily gain on milk only or milk plus concentrate diets ${ }^{1}$

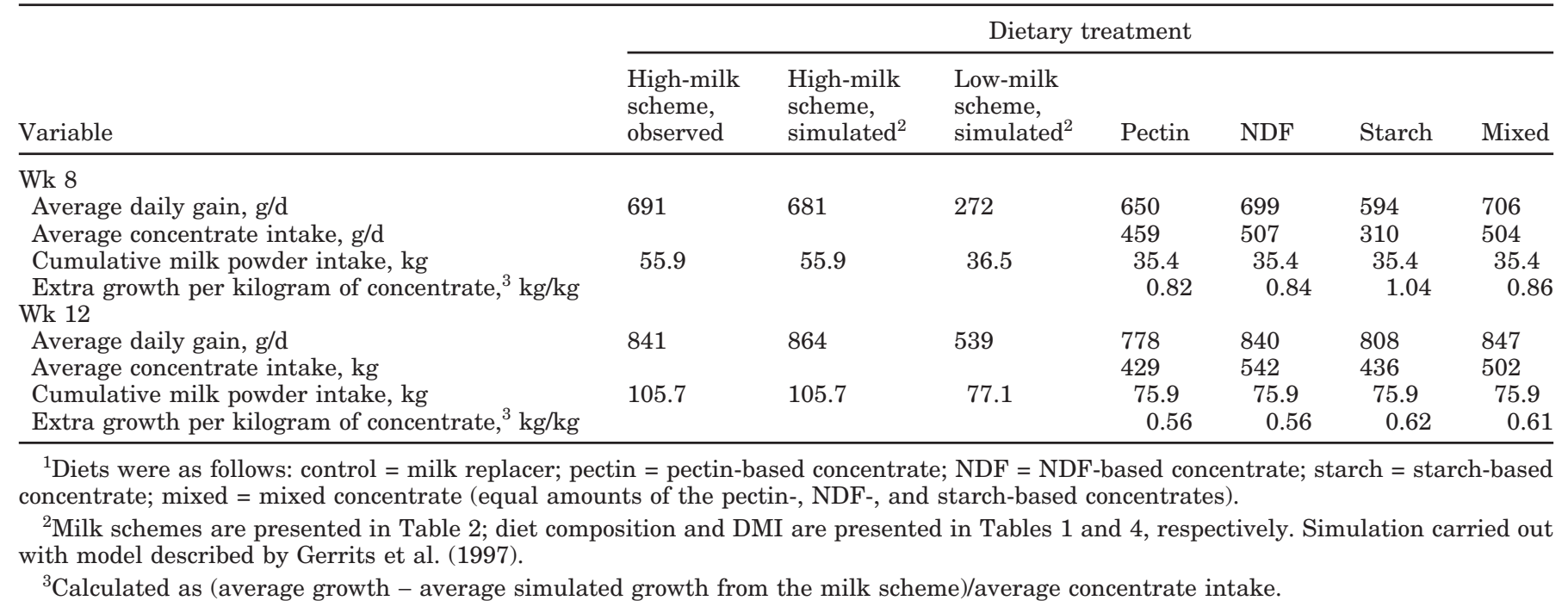

and Lesmeister and Heinrichs (2004), in which rumencannulated calves were used. These researchers observed a rumen $\mathrm{pH}$ of 5.4 to 5.6 in calves between 3 and 8 wk of age (sampled 3 to $6 \mathrm{~h}$ after feeding), increasing above 5.6 to 5.8 as the calves reached 10 to $12 \mathrm{wk}$ of age.

Among the concentrates, calves fed the starch diet revealed a particularly low rumen $\mathrm{pH}(4.9)$ at $8 \mathrm{wk}$ of age. At $12 \mathrm{wk}$ of age, the rumen $\mathrm{pH}$ was slightly higher than at $8 \mathrm{wk}$, in particular for the starch diet. This rise in $\mathrm{pH}$ might indicate an increased absorption of VFA as a consequence of a more developed and mature rumen.

The VFA concentrations on the concentrate diets were close to the range normally observed in adult ruminants (120 to $160 \mathrm{mmol} / \mathrm{L}$; Bergman, 1990). Similar results were obtained in rearing calves (Quigley et al., 1992a,b; Abdelgadir et al., 1996; Beharka et al., 1998; Lesmeister and Heinrichs, 2004). As expected, the rumen VFA concentrations observed in calves fed the concentrate diets were higher (100 to $121 \mathrm{mmol} / \mathrm{L})$ than those observed in control-fed calves $(36 \mathrm{mmol} / \mathrm{L})$. The VFA concentration found in the rumen of control-fed calves suggests the presence of milk in the rumen.

In agreement with expectations (Van Soest, 1994), the NDF-based diet led to high molar proportions of acetate, the starch-based diet led to high molar proportions of propionate, and the pectin diet to high molar proportions of butyrate. At a low $\mathrm{pH}$, microorganisms may shift fermentation pathways and increased proportions of propionate and lactate occur (see review by Dijkstra, 1994). Indeed, in the present experiment, $\mathrm{pH}$ values of the rumen fluid were low and molar proportions of propionate were high $(>27 \%)$.

Hristov et al. (2001) and Ghorbani et al. (2002) reported that in feedlot cattle perceived to have subclini- cal acidosis, the lactate concentration in ruminal fluid rarely exceeded $10 \mathrm{mmol} / \mathrm{L}$. Lactate concentrations observed in the present experiment ( 5 to $11 \mathrm{mmol} / \mathrm{L}$ ) were higher than results reported in calves by Anderson et al. (1987a,b), Abdelgadir et al. (1996), and Beharka et al. (1998) but lower than those reported by Quigley et al. (1992c), ranging from 13 to $25 \mathrm{mmol} / \mathrm{L}$ [D(-) plus $\mathrm{L}(+)$ lactate]. Furthermore, the concentration of lactate present in the control-fed diet was the highest $(>20$ $\mathrm{mmol} / \mathrm{L}$ ). This information, together with the high values of ammonia in the rumen fluid $(21 \mathrm{mmol} / \mathrm{L})$, indicates fermentation of the milk replacer in the rumen. The occurrence of ruminal drinking has been well documented (Toullec and Guilloteau, 1989; Dos Santos et al., 1986) but has rarely been quantified in experiments in which concentrates are fed. Therefore, the extent to which ruminal drinking contributes to the fermentation processes observed in this experiment is unknown.

Branched-chain VFA are mainly end-products of protein fermentation and are considered a growth factor for fiber-degrading microorganisms in the rumen (Yang, 2002). Anderson et al. (1987a) showed that in rearing calves, the molar proportions of isobutyrate declined with age as feed intake increased, indicating an increased cellulolytic activity as calves aged. They also reported that the molar proportion of valerate increased until 12 wk of age, and then remained constant thereafter. In the present trial, for the concentrate-fed treatments, the molar proportions of isobutyrate $(P<0.001)$ and valerate $(P<0.05)$ decreased with age, but the ammonia concentration increased. Higher molar proportions of branched-chain VFA were expected in the milk diet, in line with the observed high ammonia concentrations. 


\section{Enzyme Activities and Soluble Sugars in Rumen Content}

Assessing the PDE activity of the microorganisms present in the rumen is a useful approach to obtain quantitative estimates of substrate degradation in the rumen. Provided that representative samples of whole rumen contents are taken and that intra- and extracellular enzymes are completely extracted and their activity is well preserved, the relationship between substrate degradation in vitro and their degradation in vivo should be good. Silva et al. (1987) reported a high correlation $(\mathrm{r}=0.98)$ for in sacco DM degradation and cellulolytic activity after $24 \mathrm{~h}$ of rumen incubation.

In contrast with other in vitro techniques regularly used to characterize substrate degradation in the rumen (e.g., Tilley and Terry, 1963; cumulative gas production technique) the enzyme assay does not have the disadvantage of isolating the microflora and its adaptation to the incubation medium and substrate. Nevertheless, interassay variation of the analysis of enzymes is large, and procedural standardization among research groups applying this technique is lacking. Furthermore, the selection of substrates, as well as their pretreatment (unpublished observations) is crucial when determining PDE activities. However, between-treatment variation remains estimable using this technique.

The results from the present experiment illustrate adaptation of the rumen microflora to the diet. The effects of diet on PDE activities (high amylase and low SBHase) are in line with those reported for high grain/ low roughage-based diets in dairy cattle (Huhtanen and Khalili, 1992; Martin and Michalet-Doreau, 1995; Hristov et al., 1999). However, the increased hydrolysis of soybean hulls of the calves on the pectin treatments, compared with the NDF treatment, is difficult to explain.

Most techniques studying substrate degradation (e.g., enzyme assay) or substrate disappearance (e.g., the in sacco technique) assume that the end-products of hydrolysis are rapidly utilized by the microbes (Dhanoa et al., 1999), resulting in concentrations of free RS in the rumen fluid close to or below the detection level. An exception to these low levels is the high levels observed in rumen fluid immediately after a meal rich in easily degradable carbohydrates, because the supply of sugars may temporarily exceed the microbial capacity to utilize these sugars (Dijkstra et al., 2002). However, the high concentrations of RS in rumen contents found in the present experiment suggest that the assumption of rapid utilization may not always be true.

In the present research, no big differences were observed in RS concentrations among treatments. Moreover, the concentration of RS varied between 45 and
$61 \mathrm{~g} / \mathrm{kg}$ of DM, whereas in dairy cows reported concentrations ranged from 0.02 to $2.57 \mathrm{mmol} / \mathrm{L}$ of rumen fluid (approximately 0.04 and $5.55 \mathrm{~g} / \mathrm{kg}$ of DM, assuming an average of $120 \mathrm{~g} / \mathrm{kg}$ of DM in the rumen contents; Hristov et al., 2000; Hristov et al., 2001; Hristov and Ropp, 2003). The relatively high concentration of RS is likely related to relatively low bacterial growth rates while high rates of substrate hydrolysis are maintained. A reduced growth rate of bacteria may be related to the low rumen $\mathrm{pH}$ observed in this experiment. A low $\mathrm{pH}$ is known to increase the energy expenditure of rumen bacteria to maintain their intracellular $\mathrm{pH}$ (Russell and Wilson, 1996) and decrease the uptake of soluble carbohydrates by ruminal microorganisms (see, e.g., Moore and Martin, 1991; Chow and Russell, 1992; Martin, 1996; Martin and Wani, 2000). Maintaining a high rate of substrate hydrolysis could be related to the (extracellular) enzymes maintaining their activity while present in the rumen. This effect may be enlarged by low rumen motility, often observed in ruminants with low ruminal pH (Dirksen, 1989, as cited in Nocek, 1997). Interestingly, it has been demonstrated that the PDE are still active far below the optimal $\mathrm{pH}$ at which the rumen bacteria produce them. For example, at $\mathrm{pH} 5.0$, ruminal-extracted cellulases still retained $\approx 65 \%$ of their maximum activity ( $\mathrm{pH}=6$; Morgavi et al., 2000), whereas the activity of cellulolytic bacteria decreases rapidly at a pH below pH 5.6 (Russell and Wilson, 1996).

\section{CONCLUSIONS}

This trial illustrates that the carbohydrate source included in the concentrate feed affects the intake, growth, and parameters of rumen fermentation in young veal calves. Concentrate intake was decreased when animals were fed the concentrate based on starch. Calves fed concentrates based on NDF had significantly higher DMI than those fed the pectin-based concentrate. Although numerically higher, the concentrate DMI of NDF-fed calves did not differ from that of calves fed the mixed concentrate. Accordingly, calves fed the mixed and NDF concentrate-based diets showed higher ADG than those fed the starch- and pectin-based diets, respectively. In general, the rumen metabolism of calves fed concentrates was characterized by a low $\mathrm{pH}$ (4.9 to 5.2), VFA concentrations between 100 and 121 $\mathrm{mmol} / \mathrm{L}$, a low acetate:propionate ratio, and high concentrations of RS. The last observation may suggest an impaired growth of the microorganisms. With the exception of the NDF diet, results of the PDE activities showed adaptation of rumen microorganisms to the diet. The mixed concentrate-based diet showed the smallest variation in rumen PDE activity. Animal performance on all experimental treatments was good, de- 
spite the low rumen $\mathrm{pH}$ and very particular type of rumen fermentation observed on some of the treatments.

\section{REFERENCES}

Abdelgadir, I. E. O., J. L. Morrill, and J. J. Higgings. 1996. Effect of roasted soybeans and corn on performance and ruminal and blood metabolites of dairy calves. J. Dairy Sci. 79:465-474.

Anderson, K. L., T. G. Nagaraja, J. L. Morrill, T. B. Avery, S. J. Galitzer, and J. E. Boyer. 1987a. Ruminal metabolic development in calves weaned conventionally or early. J. Dairy Sci. 70:1000-1005.

Anderson, K. L., T. G. Nagaraja, and J. L. Morrill. 1987b. Ruminal microbial development in conventionally or early weaned calves. J. Dairy Sci. 64:1215-1226.

Beharka, A. A., T. G. Nagaraja, J. L. Morrill, G. A. Kennedy, and R. D. Klemm. 1998. Effects of form of the diet on anatomical, microbial and fermentative development of the rumen of neonatal calves. J. Dairy Sci. 81:1946-1955.

Bergman, E. N. 1990. Energy contributions of volatile fatty acids from the gastrointestinal tract in various species. Physiol. Rev. 70:567-590.

Brunt, K. 1993. Enzymatic determination of starch content in feed and feedstuffs, Memo 93-302 [in Dutch]. Stichting Nederlands Instituut voor Koolhydraat Onderzoek, Groningen, The Netherlands.

Chow, J. M., and J. B. Russell. 1992. Effect of $\mathrm{pH}$ and monensin on glucose transport by Fibrobacter succinogenes, a cellulolytic ruminal bacterium. Appl. Environ. Microbiol. 58:1115-1120.

Dhanoa, M. S., J. France, S. Lopez, J. Dijkstra, S. J. Lister, D. R. Davies, and A. Bannink. 1999. Correcting the calculation of extent of degradation to account for particulate matter loss at zero time when applying the polyester bag method. J. Anim. Sci. 77:3385-3391.

Dijkstra, J. 1994. Production and absorption of volatile fatty acids in the rumen. Livest. Prod. Sci. 39:61-69.

Dijkstra, J., J. A. N. Mills, and J. France. 2002. The role of dynamic modelling in understanding the microbial contribution to rumen function. Nutr. Res. Rev. 15:67-90.

Dirksen, G. 1989. Rumen function and disorders related to production disease. Page 350 in Proc. VII Int. Conf. Dis. Farm Anim. Cornell Univ., Ithaca, NY.

Dos Santos, G. T., R. Toullec, R. Roger, and H. de la Grange. 1986. Caracteristiques digestives des veux de boucherie s'adaptant mal en atelier d'engraisement. Reprod. Nutr. Develop. 26(5 B):1217.

Flatt, W. P., R. Warner, and J. K. Loosli. 1958. The influence of purified materials on the development of the ruminant stomach. J. Dairy Sci. 41:1593-1600.

Genstat Committee. 2000. Reference Manual. Procedure Library PL12. R. W. Payne and G. M. Arnold, ed. VSN International, Ltd., Oxford, UK.

Gerrits, W. J. J., J. Dijkstra, and J. France. 1997. Description of a model integrating protein and energy metabolism in preruminant calves. J. Nutr. 127:1229-1242.

Ghorbani, G. R., D. P. Morgavi, K. A. Beauchemin, and J. A. Z. Leedle. 2002. Effects of bacterial direct-fed microbials on ruminal fermentation, blood variables, and the microbial populations of feedlot cattle. J. Anim. Sci. 80:1977-1985.

Hristov, A. N., T. A. McAllister, and K.-J. Cheng. 1999. Effect of diet, digesta processing, freezing and extraction procedure on some polysaccharide-degrading activities of ruminal contents. Can. J. Anim. Sci. 79:73-81.

Hristov, A. N., T. A. McAllister, and K.-J. Cheng. 2000. Intraruminal supplementation with increasing levels of exogenous polysaccharide-degrading enzymes: Effects on nutrient digestion in cattle fed a barley grain diet. J. Anim. Sci. 78:477-487.

Hristov, A. N., M. Ivan, L. M. Rode, and T. A. McAllister. 2001. Fermentation characteristics and ruminal ciliate protozoal populations in cattle fed medium- or high-concentrate barley-based diets. J. Anim. Sci. 79:515-524.
Hristov, A. N., and J. K. Ropp. 2003. Effect of dietary carbohydrate composition and availability on utilization of ruminal ammonia nitrogen for milk protein synthesis in dairy cows. J. Dairy Sci. $86: 2416-2427$.

Huber, J. T., A. G. Silva, O. F. Campos, and C. M. Mathieu. 1984. Influence of feeding different amounts of milk on performance health and absorption capacity of baby calves. J. Dairy Sci. 67:2957-2963.

Huhtanen, P., and H. Khalili. 1992. The effect of sucrose supplements on particle-associated carboxymethylcellulase (EC 3.2.1.4) and xylanase (EC 3.2.1.8) activities in cattle given grass-silage-based diet. Br. J. Nutr. 67:245-255.

ISO (International Organization for Standardization). 1978. ISO 5984: Animal Feeding Stuffs. Determination of Crude Ash. ISO, Geneva, Switzerland.

ISO (International Organization for Standardization). 1983. ISO 6496: Animal Feeding Stuffs. Determination of Dry Matter Content, Category B. ISO, Geneva, Switzerland.

ISO (International Organization for Standardization). 1998. ISO 5983 EN: Animal Feeding Stuffs. Determination of Nitrogen Content and Calculation of Crude Protein. ISO, Geneva, Switzerland.

ISO (International Organization for Standardization). 1999. ISONEN 6492 EN: Animal Feeding Stuffs. Determination of Fat Content, Category B. ISO, Geneva, Switzerland.

Kellaway, R. C., D. J. Thompson, D. E. Beever, and D. F. Osbourn. 1977. Effects of $\mathrm{NaCl}$ and $\mathrm{NaHCO}_{3}$ on food intake, growth rate and acid-base balance in calves. J. Agric. Sci. (Camb.) 88:1-9.

Lesmeister, K. E., and A. J. Heinrichs. 2004. Effects of corn processing on growth characteristics, rumen development and rumen parameters in neonatal dairy calves. J. Dairy Sci. 87:3439-3450.

Martin, S. A. 1996. Hexose phosphorylation by the ruminal bacterium Selenomonas ruminantium. J. Dairy Sci. 79:550-556.

Martin, S. A., and L. Wani. 2000. Factors affecting glucose and maltose phosphorylation by the ruminal bacterium Megasphaera elsdenii. Curr. Microbiol. 40:387-391.

Martin, C., and B. Michalet-Doreau. 1995. Variations in mass and enzyme activity of rumen microorganisms: Effect of barley and buffer supplements. J. Sci. Food Agric. 7:407-413.

Morgavi, D. P., K. A. Beauchemin, V. L. Nsereko, L. M. Rode, A. D. Iwaasa, W. Z. Yan, T. A. McAllister, and Y. Wang. 2000. Synergy between ruminal fibrolytic enzymes and enzymes from Trichoderma longibrachiatum. J. Dairy Sci. 83:1310-1321.

Moore, G. A., and S. A. Martin. 1991. Effect of growth conditions on the Streptococcus bovis phosphoenolpyruvate glucose phosphotransferase system. J. Anim. Sci. 69:4967-4973.

Murdock, F. R., and R. W. Wallenius. 1980. Fiber sources for complete calf starter rations. J. Dairy Sci. 63:1869-1873.

Nocek, J. E. 1997. Bovine acidosis: Implications on laminitis. J. Dairy Sci. 80:1005-1028.

NRC. 1989. Nutrient Requirements of Dairy Cattle. 6th rev. ed. Natl. Acad. Sci., Washington, DC.

Owens, F. N., D. S. Secrist, W. J. Hill, and D. R. Gill. 1998. Acidosis in cattle: A review. J. Anim. Sci. 76:275-286.

Quigley, J. D., III, S. I. Boehms, T. M. Steen, and R. N. Heitmann. 1992a. Effects of lasalocid on selected ruminal and blood metabolites in young calves. J. Dairy Sci. 75:2235-2241.

Quigley, J. D., III, T. M. Steen, and S. I. Boehms. 1992b. Post-prandial changes of selected ruminal and blood metabolites in ruminating calves fed diets with or without hay. J. Dairy Sci. 75:228-235.

Quigley, J. D., III, L. B. Wallis, H. H. Dowlen, and R. N. Heitmann. 1992c. Sodium bicarbonate and yeast culture effects on ruminal fermentation, growth, and intake in dairy calves. J. Dairy Sci. 75:3531-3538.

Russell, J. B., and D. B. Wilson. 1996. Why are ruminal cellulolytic bacteria unable to digest cellulose at low $\mathrm{pH}$ ? J. Dairy Sci. 79:1503-1509.

Sander, E. G., R. G. Warner, H. N. Harrison, and J. K. Loosli. 1959. The stimulatory effect of sodium butyrate and sodium propionate on the development of rumen mucosa in the young calf. J. Dairy Sci. 42:1600-1605.

SAS Institute. 2002. SAS User's Guide: Statistics (Release 9.1). SAS Inst. Inc., Cary, NC. 
Schneider, D. 1976. Determination of ammonia and kjeldahl nitrogen by indophenol method. Water Res. 10:31-36.

Silva, A. T., R. J. Wallace, and E. R. Ørskov. 1987. Use of particlebound enzyme activity to predict the rate and extent of the fiber degradation in the rumen. Br. J. Nutr. 57:407-415.

Somogyi, N. 1952. Notes on sugars determination. J. Biol. Chem. 195:19-23.

Suárez, B. J., C. G. Van Reenen, W. J. J. Gerrits, N. Stockhofe, A. M. van Vuuren, and J. Dijkstra. 2006. Effects of supplementing concentrates differing in carbohydrate composition in veal calf diets: II. Rumen development. J. Dairy Sci. 89:4376-4386.

Tamate, H., A. D. McGilliard, N. L. Jacobson, and R. Getty. 1962. Effect of various diets on the anatomical development of the stomach in the calf. J. Dairy Sci. 45:408-420.

Tilley, J. M. A., and R. A. Terry. 1963. A two-stage technique for the in vitro digestion of forage crops. J. Br. Grassl. Soc. 18:104-111.

Toullec, R., and P. Guilloteau. 1989. Research into digestive physiology of the milk fed calf. Pages 37-55 in Nutrition and Digestive Physiology in Monogastric Farm Animals, E. J. Van Weerden and J. Huisman, ed. Pudoc, Wageningen, The Netherlands.
Van Putten, G. 1982. Welfare in veal calves units. Vet. Rec. 111:437-440.

Van Soest, P. J. 1994. Nutritional Ecology of the Ruminant. 2nd ed. Cornell University Press, Ithaca, NY.

Van Soest, P. J., and R. W. McQueen. 1973. The chemistry and estimation of fiber. Proc. Nutr. Soc. 32:123-130.

Van Soest, P. J., J. B. Robertson, and B. A. Lewis. 1991. Methods for dietary fiber, neutral detergent fiber, and nonstarch polysaccharides in relation to animal nutrition. J. Dairy Sci. 74:35833597.

Veissier, I., A. R. Ramirez de la Fe, and P. Pradel. 1998. Nonnutritive oral activities and stress responses of veal calves in relation to feeding and housing conditions. Appl. Anim. Behav. Sci. 57:35-49.

Wheeler, T. B., P. J. Wangsness, L. D. Muller, and L. C. Griel, Jr. 1980. Addition of sodium bicarbonate to complete pelleted diets fed to dairy calves. J. Dairy Sci. 63:1855-1863.

Yang, C. M. J. 2002. Response of forage fiber degradation by ruminal microorganisms to branched-chain volatile fatty acids, amino acids, and di-peptides. J. Dairy Sci. 85:1183-1190. 